\title{
Gene therapy and bone marrow transplantation
}

\author{
Jan Van Lunzen \\ From International Symposium HIV and Emerging Infectious Diseases 2014 \\ Marseille, France. 21-23 May 2014
}

Despite the tremendous advances in antiretroviral combination therapy over the last decade, eradication of HIV from the infected organism is still an elusive goal. Lifelong therapy is associated with potential long-term toxicity, adherence problems, and development of drug resistance. Thus, gene therapy approaches targeting viral eradication are still attractive. Here a number of studies have failed to show a clear clinical benefit yet. Current approaches were mainly limited by a low number of transduced cells and genotoxicity. The use of new vector systems and the right choice of target cells and improved transduction protocols may overcome these obstacles. Recent reports on the use of newly developed transgenes either allowing for an enrichment of transduced cells by an in vivo selection advantage or restoration of a functional immune system which is resistant to HIV infection nourished the hope for continuous progress in this field. Indeed the intriguing finding that HIV seems to be eradicated in an individual case study after stem cell transplantation with a mutant coreceptor (CCR5 delta 32 deletion) underlines the proof of the concept.

Published: 23 May 2014

Submit your next manuscript to BioMed Central and take full advantage of:

- Convenient online submission

- Thorough peer review

- No space constraints or color figure charges

- Immediate publication on acceptance

- Inclusion in PubMed, CAS, Scopus and Google Scholar

- Research which is freely available for redistribution

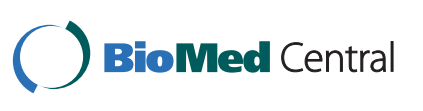

(c) 2014 Van Lunzen; licensee BioMed Central Ltd. This is an Open Access article distributed under the terms of the Creative Commons Attribution License (http://creativecommons.org/licenses/by/4.0), which permits unrestricted use, distribution, and reproduction in any medium, provided the original work is properly cited. The Creative Commons Public Domain Dedication waiver (http:// creativecommons.org/publicdomain/zero/1.0/) applies to the data made available in this article, unless otherwise stated. 